\title{
The Influence of Flexibility Training on the Accuracy of the Dollyo Chagi Kick in Taekwondo Martial Arts
}

\author{
Sandey Tantra Paramitha*, Tri Yanda Rosadi, Muhammad Gilang Ramadhan, Deni Maulana Suwanta \\ Universitas Pendidikan Indonesia \\ Bandung, Indonesia \\ *sandeytantra18@upi.edu, triyanda79@gmail.com, gilangramadhan320@gmail.com, denims568@ gmail.com
}

\begin{abstract}
This study was aimed at determining the effect of flexibility training on the accuracy of the Dollyo Chagi kick in taekwondo martial arts. The method used in this study was an experimental method. The researcher tested the effect of one independent variable (flexibility training) on one or more dependent variables (dollyo chagi kick). Independent variables in experimental research are often referred to experimental or treatment variables. Independent variable in research, also known as criterion or outcome variable, refers to the results or research outcomes. The instruments used were Kinovea and 120 FPS handicap. Kinovea is a video analysis software that can be used to analyze motion. Kinovea can be used to analyze motion variations in 2 or 3 dimensions. The subjects of this study were 16 people, consisting of 8 men and 8 women in the category of fighting (kyorugi) in accordance with the research criteria. The results of this study found that there was an increase in the accuracy of the Dollyo Chagi kick in taekwondo martial arts, after being given flexibility training in 16 meetings. The implication of this research is that taekwondo athletes can master Dollyo Chagi's kick and of course it is more accurate to be used during matches.
\end{abstract}

Keywords: dollyo chagi kick, fighting (kyorugi), flexibility training, Kinovea, 120 FPS handicap

\section{INTRODUCTION}

Taekwondo is a modern martial sport rooted in traditional Korean martial arts [1]. Taekwondo has many advantages, it not only teaches physical aspects such as fighting skills, but also strongly emphasizes teaching aspects of mental discipline and ethics [2]. Thus, Taekwondo will form a strong mental and ethical attitude for people who earnestly study Taekwondo properly [3]. This is in line with what is needed by a sports athlete, especially in the taekwondo martial arts branch to achieve the best performance [4]. One aspect that needs to be fostered to achieve a good achievement is by fostering physical conditions. Physical condition is the most important factor in achieving high achievement, athletes who have good physical condition will be better prepared in facing the training process [5]. In fostering this physical condition, there are four components that need attention, namely: flexibility, speed, strength and endurance. The four components are interrelated and one cannot be marginalized [6].

In achieving the best achievements, taekwondo martial arts have movement techniques that must be mastered properly and correctly by an athlete in order to defeat his opponents [7]. But indeed in taekwondo martial arts this sport is more dominant in the kick technique compared to the punch technique or with other techniques [8]. Taekwondo has a variety of kick techniques and each kick technique has different levels of difficulty, including: ap chagi, dollyo chagi, dwihurigi, ap hurigi, yap chagi and others [8]. In this case, the authors made observations on taekwondo athletes who performed one of the dollyo chagi kicking techniques. Dollyo chagi is a basic kick technique that is introduced to beginners who have just started training because dollyo chagi kicks are easy to do [9]. Dollyo chagi is the kick most often used by taekwondo in athletes, but in general athletes sometimes do not know when to do it when and when what kick should be done [10]. In doing dollyo chagi kicks that need to be maintained specifically is the physical condition which is a major supporting factor in involving flexibility, and leg muscle strength which is very influential to produce quality kicks, especially in matches [11].

Therefore, of the four components previously mentioned, researchers focus more on the component of flexibility [12]. Flexibility is a trait of the musculoskeletal system that determines the range of movements that can be achieved without joint injury [13]. Flexibility is a person's ability to make movements with the broadest possible range of motion in the joints, factors are the shape of the joints, muscle elasticity, and ligaments, flexibility is not only needed by athletes but it is important for everyone to facilitate daily activities [14].

This research departs from the problem that the writer found in the field. The author found that the lack of accuracy in kicking is done by athletes, who are generally novice athletes. There are cases that athletes cannot make the right kick to the target. The author sees that the athlete is still too rigid in his movements, so his Range of Motion (ROM) has become limited [15]. Given that novice athletes should have the opportunity to develop further. If one of the basic kick techniques alone cannot be practiced properly, it is feared that there will be no progress in the other kicks. This is considering that the foundations / fundamentals in the world of sports, especially Taekwondo, are very important. Therefore the purpose of this study is to determine the effect of flexibility training on the accuracy of the Dollyo Chagi kick in taekwondo martial arts. To Support this research, the researchers have three research that can support, first [16] The purpose of this study was to evaluate the kinematic and kinetic (EMG) changes induced by varying kicking target sizes and the absence of these in Taekwondo kicking. Peak velocities and intersegment 
timing and coordination variables were used to assess the kinematic of kicking executions. Second, [17] Biomechanics' determinants of the trunk front semi-circular kick (Dollyo Chagi) in Tae-Kwon-do Represents the logical analysis of motor vehicle by which the subject of the study dealing with the phenomenon after the fragmentation of the primary elements to achieve a deeper understanding of the phenomenon as a whole. And third, [18] The purpose of this research is to determine the effect of plyometric training methods and weight training methods on the explosive power of Taekwondo dollyo chagi kicks.

\section{A. The Linkage of Flexibility to Taekwondo}

In the kyorugi taekwondo especially the dollyo chagi kick, flexibility is needed to support the kicking motion, when kicking towards the upper target [19]. Thus, flexibility is an important motoric component that must be trained and improved, especially for young athletes [20]. The development of one's flexibility is influenced by age. The development of flexibility at each age level is different. In general, small children have more flexible / flexible muscles. The situation will continue to increase in the teens (school age) [21]. As they enter adolescence, their flexibility tends to reach the peak of their development. Thus it is clear that flexibility plays a very large role in learning movement skills and in optimizing other physical abilities [22]. To develop speed in taekwondo sports athletes must be fast must have a large amplitude of leg movements to be able to produce strong and fast kicks [23]. In other words, without speed the kick speed does not develop optimally. Taekwondo athletes when kicking strongly and directed without being supported by the ability to flex the joints of the body, shoulders, legs and hands, because flexibility is needed to optimize the use of leg power, shoulders, abdominal muscles and waist rounds to kick [24].

\section{B. Dollyo Chagi's Kick}

Dollyo chagi is one of the kicks that produces high points in the direction of the target up in the head inside (legal scoring area) [17]. Dollyo Chagi is a kick that is often used especially for beginner athletes in Taekwondo martial arts, there are several situations where when athletes take a kick incorrectly as instructed by the coach, one of the causes is the lack of flexibility [18]. Dollyo chagi is a basic kick technique that is introduced to beginners who have just started training because dollyo chagi is easy to do [16]. Dollyo chagi in taekwondo is one of the most basic kicks taught at the white belt level and is the foundation of many advanced kick variations [25]. Because there are many variations of kicks, and the high effectiveness of these kicks in battle or competition, dollyo chagi is a very important kick [26].

In doing a Dollyo Chagi kick, there are 5 simple steps you can take [17], namely:

- From the Kyorugi junbi position (fighting horses) lift your knees straight forward, the body remains straight facing forward.
- Rotate the waist so that the folds of the foot flatten forward and the heel on the footstool (shaft) pushes forward.

- Sent your feet straight ahead, until they form an angle of about 45 degrees.

- Fold the kicking leg again, usually called a snap.

- Pull the kicking leg back when training one leg in place (may also go forward, if you want to change legs immediately, move forward).

The strength of this kick apart from knees is also greatly supported by waist rotation which is actually a channel of energy from the body. This kick basically also uses the foot cushion (ap chuk) or instep (baldeung) when used in a match [27].

\section{METHOD}

This research uses a quantitative approach using experimental methods. In experimental research, researchers will examine the effect of one independent variable (flexibility exercise) on one or more dependent variables (the results of a Dollyo Chagi kick) [28]. Independent variables in experimental research are often referred to as experimental or treatment variables. This study provides treatment in the form of flexibility exercises for 16 meetings. But before being treated, a pretest is first performed on the sample which is then given treatment until the posttest. The sampling technique used in this study is the purposive sampling technique, which is a technique with sample selection consisting of individuals who have the appropriate qualifications desired by researchers [29]. The author chooses the number of samples with criteria, namely the fighting category (kyorugi), amounting to 16 people with details of 8 sons and 8 daughters as well as students of UPI taekwondo UKM members who have just joined UPI Taekwondo UKM within a period of approximately 1 year, which is still in beginner category. The data collection technique used is to do a test using a video analysis application that is kinovea and 120 FPS hand cam. Then the data are analyzed and conclusions drawn, then discussed in detail and clearly according to what is happening in the field.

\section{RESULTS AND DISCUSSION}

The first step is to do a pretest on 16 samples consisting of 8 males and 8 females. After the pretest, the results of the dollyo chagi kick in the sample are still low.

TABLE I. KICK INDICATOR [15]

\begin{tabular}{|l|l|}
\hline \multicolumn{1}{|c|}{ Kick's Value } & \multicolumn{1}{c|}{ Category } \\
\hline $0-19$ & Very Low \\
\hline $20-39$ & Low \\
\hline $40-59$ & Middle \\
\hline $60-79$ & High \\
\hline $80-100$ & Very High \\
\hline
\end{tabular}


TABLE II. Result of Kick PRETEST Male

\begin{tabular}{|l|l|l|l|}
\hline No & \multicolumn{1}{|c|}{ Name } & Dollyo Chagi & Category \\
\hline 1 & Ahmad Latif & 33 & Low \\
\hline 2 & Adi Chandra & 33 & Low \\
\hline 3 & Agung Ramdan & 34 & Low \\
\hline 4 & Andri Oktohari & 37 & Low \\
\hline 5 & Asep Permana & 33 & Low \\
\hline 6 & Misbah Badrudin & 35 & Low \\
\hline 7 & Dani Apriono & 37 & Low \\
\hline 8 & Hanif Handoyo & 32 & Low \\
\hline
\end{tabular}

TABLE III. Result of Kick PRETESt Female

\begin{tabular}{|l|l|l|l|}
\hline No & \multicolumn{1}{|c|}{ Name } & Dollyo Chagi & Category \\
\hline 1 & Anita Kirana & 39 & Low \\
\hline 2 & Hilda Indriani & 30 & Low \\
\hline 3 & Ria Astuti & 34 & Low \\
\hline 4 & Anggi Anggraeni & 32 & Low \\
\hline 5 & Indah Pertiwi & 37 & Low \\
\hline 6 & Hana Hanifah & 35 & Low \\
\hline 7 & Intan Mutiara & 38 & Low \\
\hline 8 & Putri Mayangsari & 36 & Low \\
\hline
\end{tabular}

From these data it is obtained that the overall sample is still in the low category after a pretest using 120 FPS handicaps and using the kinovea application. Then after treatment for 16 meetings. Researchers conducted a posttest on the sample, here are the data obtained:

TABLE IV. Result of Kick Postest Male

\begin{tabular}{|l|l|l|l|}
\hline No & \multicolumn{1}{|c|}{ Name } & Dollyo Chagi & \multicolumn{1}{|c|}{ Category } \\
\hline 1 & Ahmad Latif & 73 & High \\
\hline 2 & Adi Chandra & 73 & High \\
\hline 3 & Agung Ramdan & 84 & Very High \\
\hline 4 & Andri Oktohari & 77 & High \\
\hline 5 & Asep Permana & 83 & Very High \\
\hline 6 & Misbah Badrudin & 75 & High \\
\hline 7 & Dani Apriono & 77 & High \\
\hline 8 & Hanif Handoyo & 82 & High \\
\hline
\end{tabular}

TABle V. Result of Kick Posttest Female

\begin{tabular}{|l|l|l|l|}
\hline No & \multicolumn{1}{|c|}{ Name } & Dollyo Chagi & \multicolumn{1}{|c|}{ Category } \\
\hline 1 & Anita Kirana & 79 & High \\
\hline 2 & Hilda Indriani & 70 & High \\
\hline 3 & Ria Astuti & 80 & Very High \\
\hline 4 & Anggi Anggraeni & 82 & Very High \\
\hline 5 & Indah Pertiwi & 77 & High \\
\hline 6 & Hana Hanifah & 75 & High \\
\hline 7 & Intan Mutiara & 78 & High \\
\hline 8 & Putri Mayangsari & 80 & Very High \\
\hline
\end{tabular}

From these data it was found that overall the sample experienced an increase in the ability to do dollyo chagi kicks after treatment for 16 meetings. Then the data obtained were analyzed using Statistical Product and Service Solution (SPSS) version 24 to find out how much influence the flexibility exercise has on the results of the Dollyo Chagi kick.
TABLE VI. Result of Statistical ANALysis

\begin{tabular}{|l|c|l|l|c|}
\hline \multicolumn{5}{|c|}{ Model Summary } \\
\hline Model & R & R Square & $\begin{array}{c}\text { Adjusted R } \\
\text { Square }\end{array}$ & $\begin{array}{c}\text { Std. Error of } \\
\text { the Estimate }\end{array}$ \\
\hline 1 & .392 & .154 & .089 & 9.54624 \\
\hline \multicolumn{4}{|c|}{ Predictors (Constant), Flexibility } \\
\hline \multicolumn{4}{|c|}{ Dependent Variable: Result of Dollyo Chagi's Kick } \\
\hline
\end{tabular}

Based on the data in the R Square column, it can be seen that the value of the contribution of flexibility to the results of the Dollyo Chagi kick in taekwondo martial arts is $0.154 \mathrm{x}$ $100 \%=15.4 \%$. The magnitude of this influence implies that flexibility has a strong influence with the results of the Dollyo Chagi kick.

This study was designed to determine the effect of flexibility training from static to dynamic stretching, from active warming to passive heating. Then one of the other goals is to increase ROM (Range of Motion) [30]. From the above results after conducting research from starting to pretest, the results showed that all samples were still in the low category, then carried out treatment for 16 meetings with the provision of flexibility training in order to determine the effect on the results of the dollyo chagi kicks, until the last step was done posttest and get the result is that the sample has improved mastery of the Dollyo Chagi kick technique. This means that there is a high to very high influence according to the categories obtained after the posttest [31].

Research shows static stretching as the most effective method for increasing flexibility [32]. A possible explanation for a greater increase in flexibility is that stretching reduces the viscosity of the tendon structure[33], but increases elasticity, which is mainly caused by a reduction in passive stiffness of the muscle-tendon unit and tonic reflex activity [34].

\section{CONCLUSION}

From the findings, the results obtained from 16 samples have quite varied results, but still in the same frame, which is an increase in mastery of the dollyo chagi kick technique after being treated 16 times with flexibility training. Then from the results of the data analysis above using Statistical Package for the Social Sciences (SPSS) software, it was found that the data found that the effect of flexibility training was very high on improving mastery of the Dolly kick technique in Taekwondo martial arts, both in male and female athletes. Thus that there is the effect of flexibility training on the results of the Dollyo Chagi kick in the Taekwondo martial arts sport.

\section{REFERENCES}

[1] Lee Kyung-Hoon and 빙원철, "The study on the traditional thought and modern meaning of Taekwondo," J. Korean Alliance Martial Arts., 2009.

[2] A. Turner, "Strength \& conditioning for Taekwondo athletes," Prof Strength Cond, 2009.

[3] H.B. Kim, J.A. Johnson, E.J. Lee, and P. Ha, "An investigation into the history of the taekwondo uniform since the Korean Peninsula's liberation from Japan,” Int. J. Hist. Sport, 2016. 
[19] H.-J. Kwon and J. Lee, "A Structure of Taekwondo Kyorugi Spectators' Catharsis,” J. Korean Soc. Philos. Sport. Danc. Martial Arts', 2018.

[4] C.A. Bridge, L.R. McNaughton, G.L. Close, and B. Drust, "Taekwondo exercise protocols do not recreate the physiological responses of championship combat,” Int. J. Sports Med., 2013.

[5] C.A. Bridge, J. Ferreira Da Silva Santos, H. Chaabène, W. Pieter, and E. Franchini, "Physical and physiological profiles of Taekwondo athletes," Sports Medicine. 2014.

[6] T.O. Bompa and G.G. Haff, Periodization: Theory and Methodology of Training. 5th ed. 2009.

[7] F.B. Del Vecchio, E. Franchini, A. H. M. Del Vecchio, and W. Pieter, "Energy absorbed by electronic body protectors from kicks in a taekwondo competition," Biol. Sport, 2011.

[8] W. Pieter, "Taekwondo," in The Encyclopaedia of Sports Medicine: An IOC Medical Commission Publication, Epidemiology of Injury in Olympic Sports, 2009.

[9] I. Estevan, D. Jandacka, and C. Falco, "Effect of stance position on kick performance in taekwondo," J. Sports Sci., 2013.

[10] K.A. Matsushigue, K. Hartmann, and E. Franchini, "Taekwondo: Physiological responses and match analysis," J. Strength Cond. Res., 2009.

[11] U. Moenig, "The Evolution of Kicking Techniques in Taekwondo," Rev. Artes Marciales Asiáticas, 2012.

[12] T. Bompa, "Annual Planning, Periodisation and Its Variations," FISA Coach. Dev. Program., 2012.

[13] G.P. Fife, D. O'Sullivan, and W. Pieter, "Biomechanics of head injury in olympic taekwondo and boxing," Biol. Sport, 2013.

[14] S.S.M. Fong and G.Y.F. Ng, "Does Taekwondo training improve physical fitness?," Physical Therapy in Sport. 2011.

[15] L. Nuri, N. Ghotbi, and S. Faghihzadeh, "Acute effects of static stretching, active warm up, or passive warm up on flexibility of the plantar flexor muscles of Iranian professional female taekwondo athletes," J. Musculoskelet. Pain, 2013.

[16] R. Landeo and A.S. Mcintosh, "Kinetic and Kinematic Differences Between Target and Free Kicking in Taekwondo," in 26 International Conference on Biomechanics in Sports, 2008.

[17] A.S. Zahran and A.A. Elseoufy, "Biomechanics' Determinants of the Trunk Front Semi-Circular Kick ( Dollyo Chagi ) in Tae-Kwon-Do," World J. Sport Sci., 2010.

[18] J. Solissa and J.A.P. Tangkudung, "THE EFFECT OF TRAINING METHOD AND MOTOR ABILITY TO POWER DOLLYO CHAGI KICK TAEKWONDO,” JIPES - J. Indones. Phys. Educ. Sport, 2015.
[20] M. Kazemi, M. G. De Ciantis, and A. Rahman, "A profile of the Youth Olympic Taekwondo Athlete.," J. Can. Chiropr. Assoc., 2013.

[21] E. Casolino et al., "Technical and tactical analysis of youth taekwondo performance," J. Strength Cond. Res., 2012.

[22] F. Tornello, L. Capranica, C. Minganti, S. Chiodo, G. Condello, and A. Tessitore, "Technical-tactical analysis of youth Olympic taekwondo combat," J. Strength Cond. Res., 2014.

[23] F. Tornello, L. Capranica, S. Chiodo, C. Minganti, and A. Tessitore, "Time-motion analysis of youth olympic taekwondo combats," J. Strength Cond. Res., 2013.

[24] D.R. Mailapalli, J. Benton, and T. W. Woodward, "Biomechanics of the Taekwondo axe kick: A review,” J. Hum. Sport Exerc., 2015.

[25] J. Sadowski, D. Gierczuk, J. Miller, and I. Cieśliński, "Success factors in elite WTF taekwondo competitors," Arch. Budo, 2012.

[26] F. Topal, Volkan; Ramazanoglu, Nusret; Yılmaz, Semih; Camliguney, A.Filiz; Kaya, "The effect of resistance training with elastic bands on strike force at taekwondo," Am. Int. J. Contemp. Res., 2011.

[27] Performance Optimization in Taekwondo: From Laboratory to Field. 2014.

[28] J.R. Fraenkel and N.E. Wallen, "Methodology glossary - don't cite," in How to Design and Evaluate Research in Education, 1993.

[29] J.R. Fraenkel and N. E. Wallen, "Methodology glossary," How to Des. Eval. Res. Educ., 2009.

[30] A.L. Thornton, C.W. McCarty, and M.J. Burgess, "Effectiveness of lowlevel laser therapy combined with an exercise program to reduce pain and increase function in adults with shoulder pain: A critically appraised topic," J. Sport Rehabil., 2013.

[31] R. Mandavi, M. Ghasemi, M. Bakhtyarikia, and M. Mohammadizadeh, "Modeling areas exposed to oil pollution in the coastal city of bandar abbas using ELECTRE-I and AHP models,” J. Environ. Stud., 2017.

[32] K.J. Hill, K.P. Robinson, J.W. Cuchna, and M.C. Hoch, "Immediate effects of proprioceptive neuromuscular facilitation stretching programs compared with passive stretching programs for hamstring flexibility: A critically appraised topic,” J. Sport Rehabil., 2017.

[33] M.H., "How we select a patient for SFA intervention," Cardiovasc. Intervent. Radiol., 2010.

[34] P.W. Stubbs et al., "History-dependence of muscle slack length following contraction and stretch in the human vastus lateralis," J. Physiol., 2018. 